\title{
Anabases
}

ANABASES Traditions et réceptions de l'Antiquité

$26 \mid 2017$

Varia

\section{Setting the stage for Hittite studies in Victorian England: practices and methods of the $1870 \mathrm{~s}$}

Setting the stage for Hittite studies in Victoria England: practices and methods

of the $1870 \mathrm{~s}$

\section{Silvia Alaura}

\section{(2) OpenEdition}

\section{Journals}

Electronic version

URL: http://journals.openedition.org/anabases/6209

DOI: $10.4000 / a n a b a s e s .6209$

ISSN: 2256-9421

Publisher

E.R.A.S.M.E.

Printed version

Date of publication: 1 November 2017

Number of pages: 33-52

ISSN: 1774-4296

\section{Electronic reference}

Silvia Alaura, "Setting the stage for Hittite studies in Victorian England: practices and methods of the 1870 s", Anabases [Online], 26 | 2017, Online since 01 November 2020, connection on 19 January 2021. URL: http://journals.openedition.org/anabases/6209 ; DOl: https://doi.org/10.4000/anabases.6209 


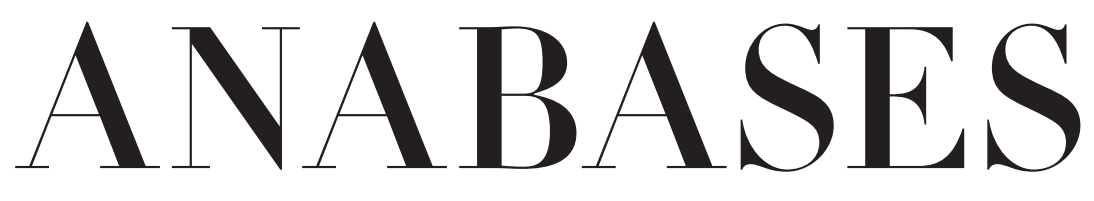

Traditions et Réceptions de l'Antiquité

$$
\begin{aligned}
& N \circ 26 \\
& 2017
\end{aligned}
$$

\section{E.R.A.S.M.E.}

Université Toulouse - Jean Jaurès 



\section{Sommaire}

$\mathrm{N}^{\circ} 26-2017$

\section{Historiographie et identités culturelles}

Jocelyne Peigney

La polysémie poétique d'anabase chez Saint-John Perse :

évocations, étymologie et botanique $\ldots \ldots \ldots \ldots \ldots \ldots \ldots \ldots \ldots \ldots$

Nicolas FAELLI

Les références antiques des fondateurs de l'Amérique française

au XVII siècle ................................. I9

Silvia Alaura

Setting the stage for Hittite studies in Victorian England:

practices and methods of the 1870 . . . . . . . . . . . . .

\section{Traditions du patrimoine antique}

“ Restituer Herculanum I. Des archives de fouilles aux restitutions 3D »

Alexandra Dardenay et Adeline Grand-Clément

Restituer Herculanum au XXI ${ }^{\mathrm{e}}$ siècle. L'apport des archives. . . . . . . . 55

Antonella Coralini

In situ e alibi, dallo scavo integrato alla cultura dell'abitare :

Vesuviana-DHER a Ercolano . . . . . . . . . . . . . . . . 67 67

Agnes Allroggen-Bedel

I documenti settecenteschi come strumenti per lo studio

degli scavi ercolanesi . . . . . . . . . . . . . . . Io3

James ANDREws

Revisiting the upper floors of the casa di Argo at Herculaneum . . . . . . II7 
Nicolas MonteIx

Les archives des fouilles d'Herculanum au XX $\mathrm{XX}^{\mathrm{e}}$ siècle :

analyse critique et pistes d'exploitation . . . . . . . . . . I43

\section{Archéologie des savoirs}

Yannick Le PAPE

L'inspiration et l'imprudence. Poésie de l'anticomanie

dans la critique d'art du second XIX ${ }^{\mathrm{e}}$ siècle . . . . . . . . . . . . . I57

\section{Actualités et débats}

Claude AzızA

Antiquités parallèles (7). La starlette des bandelettes . . . . . . . . . I77

Alexandra TrachseL

La réception d'Homère dans le domaine de la rhétorique $\ldots \ldots \ldots$. . . I83

Claude Aziza

Curiosa (2) In vino (vin/eau) veritas (very tasse) : drame de l'ivresse . . . . I89

\section{Lire, relire la bibliothèque des sciences de l'Antiquité}

Laurent OLIVIER

Pour en finir avec la race : Henri Hubert et l'anthroposociologie

À propos du commentaire de “L'Aryen, son rôle social », de Vacher de Lapouge $(\mathrm{r} 899) \ldots \ldots \ldots$

Henri Hubert

Compte rendu de Georges VACher de LAPouge, L'Aryen, son rôle social, L'Année sociologique, igoo, p. i45-146 . . . . . . . . . . . . . . . . . 203

\section{L'atelier de l'histoire : chantiers historiographiques}

L'Atelier des doctorants (coordonné par Adeline Grand-Clément) (14)

Francesco LoDÀ,

L'initiation des guerriers chez les peuples indo-européens.

Une enquête historiographique dans les pas de Georges Dumézil . . . 207

\section{Comptes rendus}

Benjamin Anderson et Robert G. Ousterhout

Palmyra I885. The Wolfe Expedition and the photographs

of John Henry Haynes (M. Sartre) . . . . . . . . . . . . . . . . . . . 2 215 
Mary R. BAchvarova

From Hittite to Homer. The Anatolian Background of Ancient Greek Epic (G. Hoffmann) . . . . . . . . . . . . . . . . .

Patrick Baker, Ronny Kaiser, Maike Priesterjahn, Johannes Helmrath (éd.) Portraying the Prince in the Renaissance. The Humanist Depiction of Rulers in Historiographical and Biographical Texts (G. Demelemestre). . 220

Brigitte BAKHоUсHE (éd.)

Science et exégèse. Les interprétations antiques et médiévales du récit biblique de la création des éléments (Genèse I, I-8) (F. P. BARONE) . . . . . . .

Laurence Baurain-Rebillard (éd.)

Héros grecs à travers le temps : autour de Persée, Thésée, Cadmos et Bellérophon (C. Giovénal) . . . . . . . . . . . . . . . .

Mark W. PAdiLla,

Classical myth in four films of Alfred Hitchcock . . . . . . . . . . . . . . .

Vivien Bessieres

Le Péplum et après? L’Antiquité gréco-romaine dans les récits contemporains (Cl. Aziza) . . . . . . . . . . . . . . . . . 225

Pierre Briant

Alexandre. Exégèse des lieux communs (É. Guillon) . . . . . . . . . . . . . 227

Paulo ButTi DE Lima

Il piacere delle Immagini. Un tema aristotelico nella riflessione moderna sull'arte (C. Noacco) . . . . . . . . . . . . . . . . . . .

Bénédicte Coudì̀re

La truelle et le phylactère. La proximité des images (M. Scapin) . . . . . . . 23I

Thorsten Fögen, Richard WARREN (éd.)

Graeco-Roman Antiquity and the Idea of Nationalism in the rgth Century, Case Studies (M. Champier) . . . . . . . . . . . . . . . ${ }_{232}$

Ronald H. Fritze

Egyptomania. A History of Fascination, Obsession and Fantasy

(Fabien Bièvre-Perrin) . . . . . . . . . . . . . . . . . . . . . 234

Joseph Geiger

Hellenism in the East. Studies on Greek Intellectuals in Palestine

(C. Bonnet). . . . . . . . . . . . . . . . . 236

Tiffany Jenkins

Keeping their marbles. How the treasures of the past ended up in museums... and why they should stay there (C. Valenti) . . . . . . . . . . 238 
Ayelet H. Lushkov

Magistracy and the Historiography of the Roman Republic.

Politics in Prose (C. Landrea) . . . . . . . . . . . . . . . . . . . . . . 240

Jean-Claude MüHLEthaler

Énée le mal-aimé. Du roman médiéval à la bande dessinée

(Fl. Bouchet) ........................ 24I

Laurent PERNoT

Epideictic Rhetoric, Questioning the Stakes of Ancient Praise

(C.Psilakis) ......................... 243

Priscian

Answers to King Khosroes of Persia (O. Gengler) . . . . . . . . . . . . . . 245

Paul Robertson

Paul's letters and contemporary Greco-Roman literature:

theorizing a new taxonomy (M. Cambron-Goulet) . . . . . . . . . . . . . . 247

Federico Santangelo (éd.)

Approaching the Roman Revolution. Sir Ronald Syme,

Papers on Republican History (C. Landrea) . . . . . . . . . . . . . . . . . . 249

Molly Swetnam-BurLand

Egypt in Italy. Visions of Egypt in Roman Imperial Culture

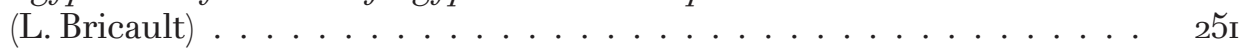

Helen VAN Noorden

Playing Hesiod. The 'Myth of the Races' in Classical Antiquity

(D. Bonanno)

Résumés . . . . . . . . . . . . . . . . . . . . . . . . . . . . . . . 257

Index .......................... . . 265 


\section{Historiographie et identités culturelles}





\section{Setting the stage for Hittite studies in Victorian England: practices and methods of the $1870 \mathrm{~s}$}

Silvia Alaura

The principal stage on which Hittite studies began was the mid-Victorian England of the 1870s. They fit into the wider context of the beginning of Assyriological studies, which in England had as their founding moments in the middle of the century the arrival at the British Museum of the Assyrian reliefs and of the cuneiform tablets from the excavations led by Sir Henry Austen Layard at Nimrud and Nineveh, and the decipherment of cuneiform as a result of the competition announced by the Royal Asiatic Society in 1857.

The 1870 s were a fundamental watershed in the understanding of the various written sources and monuments to be attributed to the Hittites. For the first time, the idea was proposed that they were a people not of Palestine but of northern Syria and Anatolia. The main British discoveries that contributed to the understanding of the Hittites during the 1870s concerned the Hama Stones (from 1872 onwards) and the identification of Karkemish with the mound near Jerablus in 1876 (followed by the first excavation from 1878 onwards). The main protagonists at this earliest stage of British Hittite studies were the Irish missionary William Wright (1837-1899), a member of the British and Foreign Bible Society (BFBS), ${ }^{1}$ the pioneering English Assyriologist George Smith (1840-1876), Senior Assistant in the

1 See E. I.[rving] C.[ArLyle], "Wright, William 1837-1899", Dictionary of National Biography vol. 63, 1900, p. 139f.; U. Wright, The Rev. Dr. William Wright, 1837-1899 (The 'Burning Bush' series 5), Belfast, Presbyterian Historical Society of Ireland, 1988; H. Owen-Jones, Ten Years in Damascus. A Traveller's Tale Retracing the Life of Rev. Dr. William Wright 1865-1875, Market Harborough (UK), Troubador, 2010. 
Assyriology Department of the British Museum, ${ }^{2}$ and the English philologist Rev. Archibald Henry Sayce (1845-1933), a Church of England curate, then Professor of Comparative Philology and later of Assyriology at Oxford. ${ }^{3}$

Research currently under way based on correspondence and other archival records mainly kept in London, Oxford and Cambridge, the preliminary results of which I present here, aims to elucidate lesser-known details of the events and to provide a fuller picture of the practices and methods of the 1870s.

\section{The casts of the Hama Stones in the PEF's London exhibition of 1873}

In the summer of 1873, the Dudley Gallery at the Egyptian Hall in Piccadilly, a well-known entertainment venue in London, was chosen by the Palestine Exploration Fund $(\mathrm{PEF})^{4}$ for an exhibition of watercolour sketches and photographs of Palestine and of a collection of various objects that came from the Survey of

2 See A.H. Sayce, "George Smith", Nature 14 (1876), p. 421f.; B. Hoberman, "George Smith (1840-1876) Pioneer Assyriologist", The Biblical Archaeologist 46/1 (1983), p. 41f.; S.M. Evers, "George Smith and the Egibi Tablets", Iraq 55 (1993), p. 107-117; S.V. Panayotov, C. Wunsch, "New Light on George Smith's Purchase of the Egibi Archive in 1876 from the Nachlass Mathewson", in M.J. Geller (ed.), Melammu. The Ancient World in an Age of Globalization (Max Planck Research Library for the History and Development of Knowledge 7), Berlin, 2014, p. 191-199.

3 See E.A. W. Budge, The Rise and Progress of Assyriology, London, Hopkinson, 1925, p. 185-188; J. Garstang, "Archibald Henry Sayce", $A A A 20$ (1933), p. 195f.; S.H. Langdon, "Archibald Henry Sayce", AJO 8 (1932-33), p. 341f. and "Archibald Henry Sayce as Assyriologist", Journal of the Royal Asiatic Society of Great Britain and Ireland 2 (Apr. 1933), p. 499-503; B. GunN, "Sayce, Archibald Henry (1845-1933)", Dictionary of National Biography 1931-1940, 1949, p. 786-788; R.L. Belton, A NonTraditional Traditionalist: Rev. A.H. Sayce and His Intellectual Approach to Biblical Authenticity and Biblical History in Late-Victorian Britain (Diss. Louisiana State University), Baton Rouge, 2007.

4 The PEF was founded as an independent membership society in 1865 "for the purpose of investigating the Archaeology, Geography, manners, customs and culture, Geology and Natural History of the Holy Land". See J.J. Moscrop, The Palestine Exploration Fund, 1865-1914 (PhD thesis, Leicester, 1996), later revised and published as Measuring Jerusalem: The Palestine Exploration Fund and British interests in the Holy Land, London, Leicester University Press, 2000. During the 1870s, the main PEF project was the Survey of Western Palestine (1871-1878). At the time of the exhibition, the PEF Committee had just published a book entitled Our Work in Palestine: A popular Account of the objects of the Fund, and its Work to the End of 1872, London, Bentley 1873, 350 pages with 50 ill., London, 1872, which gave a clear account of the work of the PEF since its foundation. 
Western Palestine or that had been collected by others who had worked and travelled in that region. ${ }^{5}$ Among other exhibits, there were the newly obtained casts of the stones from the Syrian city of Hama, inscribed with then unknown hieroglyphic signs today known as Luwian or Anatolian Hieroglyphs. ${ }^{6}$ The casts had been made some months earlier, in December 1872, and had only just arrived in London. The photographs of the Hama Stones were included in the selection of 100 photographs that could be purchased by subscribers for $£ 4$ and by nonsubscribers for $£ 5 .^{7}$ For the Victorian public - already familiar with the sites of the Holy Land - the main interest in the Hama Stones lay in their mysterious script, which had not yet been deciphered, and in the fact that they were regarded by the natives in Syria with superstitious awe, as the exhibition catalogue explained.

The casts of the Hama Stones were exhibited along with the cast of the "Deluge Tablet" (known to modern scholarship as the eleventh tablet of the Epic of Gilgamesh), just discovered among the Nineveh tablets of the British Museum by Smith, who in 1872 had achieved worldwide fame by presenting and translating it in a lecture whose audience included the Archbishop of Canterbury and the Prime Minister, W.E. Gladstone. ${ }^{8}$ The Mesopotamian composition offered a parallel to the biblical narrative (Genesis 6-7) and predated it by several centuries. It is therefore easy to see why Smith's discovery should have caused such a stir.

Clearly, the PEF wanted the public visiting the Dudley Gallery to be inspired with the idea that the Hama Stones, once deciphered, could reveal information just as sensational as the "Deluge Tablet". And sensational discoveries were just what the public expected from the exhibitions. From the early years of the PEF, its expositions were both an educational and financial undertaking. On the one hand, they aimed to make new materials rapidly available to scholarly research. But they were also a space in which conversation and networking were as important as educational enrichment. The exhibitions encouraged sponsorship of archaeological work in the Holy Land and its promotion to a fascinated and wealthy public. They aimed to persuade visitors to join the society and support it by contributing money to its work in a period when the PEF was in dire financial

5 See the Catalogue of Water-Colour Sketches, Tracings, Models, Photographs, Pottery, $\& c$., exhibited by the Palestine Exploration Fund, London, 1873. The Egyptian Hall was demolished in 1905. Egyptian House, at 170-173 Piccadilly, now occupies the site.

6 Catalogue of Water-Colour Sketches, 1873, p. 21 (nos. 99-100) and 27.

7 See the priced catalogue of the photographs, p. 9 of the Catalogue of Water-Colour Sketches, 1873.

8 G. Sмітн, "The Chaldean Account of the Deluge", Transactions of the Society of Biblical Archaeology (TSBA) 2 (1873), p. 213-234. 
trouble. ${ }^{9}$ And the inscriptions were undoubtedly among those objects that could command a great deal of attention. It has been remarked that "the Saturday Review [of 29 August 1868] explained that Joseph's mummy was not necessary: even a crock of Jewish gold, a vessel or two of the Temple, or a stone 'incised with some undoubted Scriptural name' would have acted like a prophet's rod 'in letting forth the waters of public munificence". ${ }^{10}$

\section{The making of the Hama Stones casts}

The casts of the Hama Stones had been made by Rev. Wright, supported by the vice-consul in Damascus, W. Kirby Green. ${ }^{11}$ Green presented the original casts of the Hama Stones to the Foreign Secretary, Lord George Granville, who handed them over to the British Museum. The duplicates of the casts of the Hama Stones, on the other hand, were brought to the PEF in London (where they remain to this day) by Capt. Richard Burton, explorer and then consul at Damascus, who at that time in Syria was acting as an intermediary between the Turks and the PEF. ${ }^{12}$ In 1871 Burton himself and Charles Tyrwhitt Drake, a PEF member who was staying in Damascus by March 1871, had unsuccessfully made copies, photographs and squeezes of the Hama Stones. ${ }^{13}$

Wright was in Syria from 1865 to 1876 on behalf of the British and Foreign Bible Society (BFBS), a non-denominational Christian Bible society founded in 1804 with charity status, whose purpose was to make the Bible available throughout

9 For the financial situation of the PEF in the summer of 1873 see PEF/MINS 17.7.1873, quoted by Moscrop, The Palestine Exploration Fund, p. 103, and see also p. 232.

10 E. Bar-Yosef, The Holy Land in English Culture 1799-1917. Palestine and the Question of Orientalism (Oxford English Monographs), Oxford, Clarendon Press, 2005, p. $175 f$. and n. 202.

1 See W. Wright, "The Hamah Inscriptions", Palestine Exploration Fund Quarterly Statement 5.2 (April 1873), p. 74-77. A detailed retrospective account can be found in W. Wright, The Empire of the Hittites, London, J. Nisbet \& co., 1884, p. 1-12 and W. Wright, The Hittites up to Date. A lecture delivered for the Palestine Exploration Fund, London, PEF, 1892, p. 24-34.

12 The casts still form part of the collection of casts of objects and inscriptions from PEF explorations, the originals of which were either transferred to Istanbul during the Ottoman era or remained in Jerusalem; see F. Соввіng, "The Palestine Exploration Fund: The Collections of an Historic Learned Society in London", Journal of Eastern Mediterranean Archaeology \& Heritage Studies 5/1 (2017), p. 75-87. See also http:// www.pef.org.uk/casts/.

13 See Moscrop, The Palestine Exploration Fund, p. $95 \mathrm{ff}$. 
the world. ${ }^{14}$ Documents concerning Wright's activity in Syria await scholarly examination in the BFBS and PEF archives. ${ }^{15}$

The British investigation of the Hama Stones in the first half of the 1870s was therefore undertaken by diplomats and missionaries linked to the work of the PEF and, by their own admission, was the result of unplanned circumstances and their own personal interest in history and archaeology. Burton wrote that "it was mainly a labour of love, undertaken amidst a variety of occupations, interrupted by business of a public as well as a private nature, and intended chiefly to supplement the geographical studies and explorations which occupied the greater part of my spare time". ${ }^{16}$ And for Wright, his interest in the Hama Stones formed part of what he himself described, years later, as "incidents of a residence in Syria during nine stirring years". ${ }^{17}$

Actually, the PEF was spurred to deal with the Hama Stones by a linguistic interest stemming from Cambridge University. Indeed, the importance of their inscriptions and the need to have casts of them available in England was pointed out to Walter Besant, writer and Secretary of the PEF, by the noted explorer and Arabist Edward Henry Palmer, Fellow of St John's College and later Lord Almoner's Professor of Arabic at the University of Cambridge. Palmer was taking part in the PEF Survey North of Sinai, in the desert of Tih (1869-1870), together with Tyrwhitt Drake, under a grant from Cambridge University's Travelling Bachelor's Fund. ${ }^{18}$ Palmer came to understand the great interest in the Hama Stones during his stay

14 For a history of the BFBS see L. Howsam, Cheap Bibles: Nineteenth-Century Publishing and the British and Foreign Bible Society (Cambridge Studies in Publishing and Printing History), Cambridge, Cambridge University Press, 2002 rev. ed.; W. Canton, A History of the British and Foreign Bible Society, 5 vols., London, John Murray, 19041910, particularly for Wright vol. 3, p. 27f. and vol. 4, p. $205 \mathrm{f}$.

15 For a history of the archives of the BFBS see K. CAnN, "The Archives of the British and Foreign Bible Society", and "Appendix: A Summary Catalogue of the BFBS Society", in S.K. Batalden, K. Cann, J. Dean (eds), Sowing the Word: The Cultural Impact of the British and Foreign Bible Society, 1804-2004, Sheffield, Sheffield Phoenix Press, 2004, p. 14-23, 344-359. For the archives of the PEF see http:/www.pef.org.uk/.

16 R.F. Burton, "Anthropological Collections from the Holy Land. No. III. Notes on the Hamah Stones, with Reduced Transcripts", Journal of the Anthropological Institute of Great Britain and Ireland II (1873), p. 52.

17 W. Wright, An account of Palmyra and Zenobia, with travels and adventures in Bashan and the desert, London, Edinburgh \& New York, T. Nelson \& Sons, 1895, p. ix (Preface).

18 See Moscrop, The Palestine Exploration Fund, p. 146ff. and Measuring Jerusalem, p. $95 \mathrm{ff}$. 
in Beirut, when he saw the copies of them made in 1870 by two Americans, the consul Augustus Johnson and the missionary Rev. Samuel Jessup. ${ }^{19}$

Furthermore, as may be seen from a letter from Besant to D.C. Gilman of the American Palestine Exploration Society (APES) of 9 February 1871, Palmer had already seen copies of these inscriptions in a manuscript kept at the University of Cambridge. ${ }^{20}$ It will perhaps be possible to verify whether Palmer had seen them in the papers of the Swiss explorer Johann Ludwig Burckhardt, who was the first to describe one of the Hama Stones, now known as HAMA 4. ${ }^{21}$ The diaries of Burckhardt's trips, including the journey from Aleppo to Damascus in February and March 1812, during which he visited Hama, were published posthumously in 1822 by the Association for Promoting the Discovery of the Interior Parts of Africa. ${ }^{22}$ In this publication, the mention of the Hama hieroglyphic inscription is not accompanied by an illustration, ${ }^{23}$ but I would not exclude the possibility that Burckhardt might have made a copy of it. After Burckhardt's death, the University of Cambridge, where he had studied, inherited his collection of Arabic manuscripts together with his private documents, which arrived in 1819. My hypothesis is that in the 1860s, Palmer, during his residence at St John's College, while he was cataloguing the Arabic and Persian manuscripts of the King's and Trinity College Libraries and afterwards those of the University Library, ${ }^{24}$ may have seen copies of the Hama hieroglyphic inscription in Burckhardt's papers, which have not yet been adequately studied. ${ }^{25}$

19 For the parallel activity of the American PEF and its relations with its British counterpart see F.J. Соввing, "The American Palestine Exploration Society and the Survey of Eastern Palestine”, PEQ 137/1 (2005), p. 9-21.

20 D.C. Gilman, "On the Work of the Palestine Exploration Fund, Proceedings at Boston, May 17th, 1871", JAOS 10 (1872-1880), p. xii-xiii. See also J. Augustus Johnson, "Inscriptions discovered at Hamath in Northern Syria", American Exploration Society. Quarterly Statement 1, reprinted in PEF's Quarterly Statement 3 (1871), p. 173-176, ref. p. 175 .

21 See J.D. Hawkins, Corpus of hieroglyphic Luwian inscriptions. Vol. I. Inscriptions of the Iron Age (Untersuchungen zur indogermanischen Sprach- und Kulturwissenschaft n.F. 8.1), Berlin - New York, De Gruyter, 2000, Part 2, p. 403-406.

22 J.L. Burckhardt, Travels in Syria and the Holy Land, London, J. Murray, 1822, p. $146 f$.

23 Perhaps in view of the difficulties and costs of reproducing the inscriptions (on this aspect see the Preface of the editor, William Martin Leake, acting Secretary of the African Association, to Burckhardt, Travels in Syria and the Holy Land, p. xvii).

24 W. Besant, Sir, The Life and Achievements of Edward Henry Palmer, London, Murray, 1883, p. 41 with n. 1.

25 See C. Ansorge, The man who discovered a 'lost' wonder of the world, 22 Aug 2012, at: http://www.cam.ac.uk/research/news/the-man-who-discovered-a-\%E2\%80\%981 ost $\%$ E2\%80\%99-wonder-of-the-world. 


\section{The first studies of the Hama Stones}

When in 1873 the Hama Stones were exhibited by the PEF in order to bring them to the notice of a wider public, they were already well known to a circle of scholars, and an international debate had sprung up around them. Indeed, in 1872 detailed drawings of the Hama Stones were published by Burton in a monograph on the exploration of Syria, giving them wide exposure. ${ }^{26}$ The volume included an essay by the engineer and philologist Hyde Clarke in which, intending to show that the inscriptions were genuine writing and not "vagaries of ornamentation", he presented his initial hypotheses, which were reaffirmed in the PEF's Quarterly Statement of April 1872. ${ }^{27}$ And Burton gave a lecture on the Hama Stones on 4 March 1872 in London at the Anthropological Institute of Great Britain and Ireland $^{28}$ - British anthropology's new arena of dispute and a forum for the "scientific" study of racial difference - which had just been founded (1871) as the result of a merger between the Anthropological Society of London (ASL), whose presidential chair Burton himself first occupied, and the Ethnological Society of London (ESL). ${ }^{29}$ Indeed, the debate about the Hama Stones began and developed at a time when evolutionary thought was emerging in the human sciences, ${ }^{30}$ and it partly intersected with it. The Anthropological Institute of Great Britain and Ireland was an ideal venue during the 1870 s for the nascent debate on the Hittites and related topics.

Burton and Clarke were not the only members of the PEF to take an interest in the Hama Stones. Towards the end of that same year, on 20 November 1872, Rev. Dunbar Isidore Heath wrote a letter from Esher, Surrey, to Besant from which we learn that Heath had spent months working on the Hama inscriptions. He wrote that, although he had not made progress in deciphering them, he was

26 R.F. Burton, C.F.T. Tyrwhitт Drake, Unexplored Syria, London, Tinsley Brothers, 1872, vol. I, p. 184-186 ("I believe that the five blocks of basalt at Hamah, covered with hieroglyphs in excellent preservation, may be the opening page to a new chapter in history", p. 184).

27 H. Clarke, "Note on the Hamah Inscriptions", in Burton - Tyrwhitt Drake, Unexplored Syria, I, p. 349-360; ID., "Note on the Hamath Inscriptions", Palestine Exploration Fund Quarterly Statement 4.2 (April 1872), p. $74 \mathrm{f}$.

28 Burton, "Anthropological Collections from the Holy Land ...", 1873.

29 G.W. Stocking JR., "What's in a Name? The Origins of the Royal Anthropological Institute (1837-71)", Man, New Series 6/3 (1971), p. 369-390. For Burton's role in the racial debate see D. Kennedy, The Highly Civilized Man. Richard Burton and the Victorian World, Cambridge (MA), Harvard University Press, 2005, p. 131-163.

30 E. Sera-Shriar, "Race", in M. Bevir (ed.), Historicism and the Human Sciences in Victorian Britain, Cambridge, Cambridge University Press, 2017, p. 48-76. 
convinced that he was dealing with a syllabic alphabet, as in Cypriote. ${ }^{31}$

However, it was not only British scholars who were beginning to engage with the Hama Stones, and the PEF had to work hard to ensure that their interpretations were recognised as primary. This emerges from the polemic appearing in the pages of the PEF's Quarterly Statement, in which Clarke claims priority for his studies and hypotheses. ${ }^{32}$ In the first place, the polemic was directed against Rev. William Hayes Ward of New York (who would become a prominent figure in Hittite studies), who was guilty of having just published two contributions on the Hama Stones without citing Clarke's study. ${ }^{33}$ And in the second place, the polemic also involved Sayce who, in his report on Semitic and Assyriological studies during the Third Annual Address of the President of the Philological Society delivered on 15 May 1874, had omitted to cite Clarke in connection with the Hama Stones, referring instead to the "suggestive article" by François Lenormant in the Revue Archéologique of 1873 and to Rev. Heath's study. ${ }^{34}$ Evidently, at the Philological Society, of which he was not a member and where he had been invited to speak for the first time, Sayce preferred to cite scholars with a solid reputation and in tune with his ideas. Sayce respected Heath, and indeed would accept his Cypriote hypothesis concerning the Hama Stones, whereas he was in conflict with Clarke about the relationship between language and race. ${ }^{35}$ Sayce's approval of Lenormant

31 D.I. Hеath, "The Hamath Inscriptions", Letter to the Secretary of the Palestine Exploration Fund, dated 20 November 1872, published in Palestine Exploration Fund Quarterly Statement 5.1 (January 1873), p. 35f. See also ID., "The Hamath Inscriptions", Athenaeum 28 October 1876, and "Squeezes of Hamath Inscriptions", read November 25, 1879, Journal of the Anthropological Institute IX (1880), p. 369-375 (and see also p. 337).

32 "The Second Statement of the American Palestine Exploration Society", Palestine Exploration Fund Quarterly Statement 6.3 (July 1874), p. 197.

33 W.H. WARD, "On the Hamath Inscriptions, Proceedings at New Haven, Oct $15^{\text {th }}$ and $16^{\text {th }} 1873$ ", JAOS 10 (1872-1880), p. lxxv-lxxvi and "The Hamath Inscriptions", Palestine Exploration Society (America), 2 (1873), p. 19-26 (with facsimile reproduction of four inscriptions). For Ward's contribution to nascent Hittitology see M. JAstrow, “William Hayes Ward (1835-1916): In Memoriam”, JAOS 36 (1916), p. 232-241, with Ward's bibliography in the field of oriental studies.

34 A.H. SAYce, "On Semitic and Assyrian Philology", Transactions of the Philological Society 1873-4, p. 365-377. The references are to F. Lenormant, "Lettre à M. de Saulcy, membre de l'Institut, sur quelques sceaux à légendes en écriture hamathéenne", Revue Archéologique 26 (1873), p. 226-235, and to НЕатн, "The Hamath Inscriptions", quoted above, n. 31.

35 For Clarke's and Sayce's differing opinions about Language and Race see H. Henson, "Early British Anthropologists and Language", in E. Ardener (ed.), Social Anthropology and Language, London - New York, Routledge, 2004 (first published 
highlighted his cosmopolitanism, also evidenced by the vast correspondence he undertook with foreign colleagues, which in some cases was brought to an abrupt end by the First World War. ${ }^{36}$

However, while all these hypotheses - which for the most part would soon be revealed to be erroneous ${ }^{37}$ - were being formulated in London, the Secretary of the PEF, Besant, was in possession of an unpublished manuscript by Rev. Wright that correctly attributed the Hama inscriptions to the Hittites.

\section{Wright's hypothesis of 1872}

Wright wrote two articles while he was still in Hama, at the close of 1872.

The first is a memorandum that was immediately published in the PEF's Quarterly Statement of April 1873, ${ }^{38}$ when the copies of the Hama casts had not yet arrived in London, as shown by an editorial note dated 31 March 1873. ${ }^{39}$ In the memorandum, Wright gives a detailed account of the eventful story of the making of the casts, provides a description of the stones and the inscriptions, and concludes that "they seem to have been intended to be publicly read, and were therefore doubtless in the vernacular of the people of Hamah". This essay provoked an immediate reaction from Clarke, who in the following issue of the PEF's Quarterly Statement (July 1873) wrote that he did not agree with Wright's observations and did not share his hypotheses. ${ }^{40}$

In his second article, Wright presented a historical overview of the inscriptions from Hama, arguing that they should be attributed to the Hittites. The article, clearly not considered suitable for the PEF's Quarterly Statement, was submitted by Besant to the weekly journal The Athenaeum, but without success. ${ }^{41}$ It was not

in 1971), p. 3-32, especially p. 4f.

36 See S. Alaura, "La Grande Guerre et la formation de l'Hittitologie dans le cadre des études sur le Proche-Orient ancien", in A. Fenet, S. NArdi-Combescure, M. Passini (eds), Archéologues et historiens de l'art à l'épreuve de la Grande Guerre (Colloque international École Normale Supérieure, Paris, $27-28$ janvier 2017), forthcoming.

37 Some of these hypotheses were doggedly pursued to extreme conclusions; see for example H. Clarke, The Khita and Khita-Peruvian epoch: Khita, Hamath, Hittite, Canaanite, Etruscan, Peruvian, Mexican, etc., London, Trubner \& Co, 1877.

38

39

Ibid. p. 77. Initially, it was hoped that the casts would be able to reach London in January, see "Tyrwhitt Drake Report, Haifa, Dec. 15, 1872", published in Palestine Exploration Fund Quarterly Statement 5.2 (April 1873), p. 61f.

40 H. Clarke, "Hamath Inscriptions", Palestine Exploration Fund Quarterly Statement 5.3 (July 1873), p. 115. It is possible that Clarke knew further details of Wright's hypothesis, since he comments on arguments that do not appear in the memorandum.

41 For an overview of the history of The Athenaeum in the mid- and late-Victorian 
published until 1874, "after many vicissitudes", thanks to the minister of the Regent Square Presbyterian Church of London, James Oswald Dykes, in the British and Foreign Evangelical Review, and thus in a publication not specifically devoted to oriental studies. ${ }^{42}$ The proposal that the Hama inscriptions belonged to the Hittites had never been formulated before, and was expressed very briefly by Wright, on general grounds: "From all the evidence before me, external and internal, I am inclined to believe that we have in these inscriptions some declaration from the Hittites themselves" ${ }^{43}$ The idea must date back to 1872 , because a reference by Wright to the forthcoming publication of his memorandum for the $\mathrm{PEF}^{44}$ reveals that the manuscript did not undergo revision during the period in which a publisher was being found.

It is no surprise that The Athenaeum did not accept Wright's article, which had distinctly religious overtones, like everything he wrote. William Canton, the British poet, journalist and writer, in his five-volume history of the BFBS, fittingly described the religious inspiration behind Wright's historical-archaeological work: "But, in truth, his [Wright's] delight in the desert, in the ruined cities of Syria, in the reliques of vanished dynasties his daring rides and scientific wanderings, in the course of which he penetrated to certain recesses of the Druses, and gained the confidence of that mysterious and suspicious race, were all a phase of his intense interest in the Bible, and in everything that might illumine its sacred pages." 45 Perhaps archive documents will be able to cast light on the "many vicissitudes" to which Wright refers, and will also clarify what role was played by the members of the PEF (especially those who, like Clarke, were ill-disposed towards Wright's hypothesis) in events surrounding the publication.

Even after its publication, Wright's article was not widely distributed, and consequently his proposal that the Hama inscriptions should be attributed to the

decades see L. Howsam, "Growing Up with History in the Victorian Periodical Press", in B. Konte, S. Paletschex (eds), Popular History Now and Then: International Perspectives (Historische Lebenswelten in populären Wissenskulturen - History in Popular Cultures 6), Bielefeld, Transcript Verlag, 2012, p. 65; see also L. Howsam, "Academic Discipline or Literary Genre? The Establishment of Boundaries in Historical Writing", Victorian Literature and Culture 32/2 (2004), p. 525-545 and eadem, Past into Print: The Publishing of History in Britain 1850-1950, London, British Library - Toronto, University of Toronto Press, 2009.

42 W. Wright, "The Hamah Inscriptions: Hittite Remains", British and Foreign Evangelical Review 23 (1874), p. 90-99.

43 Ibidem, p. 96.

44 Ibidem, p. 90.

45 Canton, A History of the British and Foreign Bible Society, vol. 3, p. 28. 
Hittites made no impact at all. Looking back around twenty years later, in 1892, Wright gave a lecture at the PEF in front of the casts of the Hama inscriptions in which he described, with perhaps a touch of false modesty, how he had reached his conclusions: "I claim no credit beyond the exercise of a little common sense for suggesting that the Hamah inscriptions were Hittite remains". ${ }^{46}$ The text that Wright read is more like a sermon than a history lecture, interwoven with anecdotes, direct speech and rhetorical questions. Not only were the Hittites materially "proven" to have existed, but also his outline of the rediscovery of the Hittite Empire served as a parable to show his audience that Truth always triumphs, or as a powerful metaphor for thinking about Truth and Justice: "I put on record these items in connection with the Hittites to encourage any who may have stumbled on a truth to hold by it. A little breeze of ridicule and hostility will not kill. Truth can afford to wait; she is used to it". ${ }^{47}$ And certainly the PEF, which had previously refused to publish Wright's article, was the ideal forum in which to celebrate the victory of Truth. It is not difficult to see here why Canton described Wright's character as follows: "His unbounded physical energy was singularly matched with a literary dexterity that was second only to his fervid oratory. The combination was not more strange than his love of romance and adventure and his devotion to the missionary cause". ${ }^{48}$

In Damascus, after 1874 Wright no longer occupied himself with the Hittites; perhaps he was disappointed, and certainly his time was taken up with other matters. In 1876 his wife's ill health brought him back home to Ireland, where he became Editorial Superintendent of the Society and turned his attention to the Hittites once again.

\section{Smith, the Hama Stones and Karkemish}

Shortly after the arrival in London - at the British Museum and the PEF - of the casts made by Wright, in May 1874 Smith saw in Aleppo the hieroglyphic stone inscription of the al-Qaiqan Mosque now known as ALEPPO 1. ${ }^{49}$ In 1872 Burton and Tyrwhitt Drake had published a sketch of it, and in 1873 the French orientalist Charles S. Clermont-Ganneau - employed by the British government in 1874 to take charge of an archaeological expedition to Palestine - had made a first attempt to interpret it. ${ }^{50}$ Smith worked on the Aleppo inscription and made a copy of it,

46 Wright, The Hittites up to Date, p. 40.

47 Loc. cit.

48 Canton, A History of the British and Foreign Bible Society, vol. 3, p. 27f.

49 See Hawnins, Corpus of hieroglyphic Luwian inscriptions, Vol. I, Part 1, p. 19.

50 Burton - Tyrwhitt Drake, Unexplored Syria, p. 185f.; Сh. Clermont-Ganneau, "Ideographic Inscription found at Aleppo, akin to those of Hamath", Palestine 
as shown by his sketchbook preserved in the British Library. ${ }^{51}$ But in his 1875 Assyrian Discoveries, the Aleppo inscription is discussed without reproducing a copy of it. ${ }^{52}$

Understandably, this is a lesser-known episode in Smith's rather romantic life and brilliant career, and one that is given little emphasis in the history of Hittitology. Nevertheless, it is highly significant, since it represents the beginning of his attempt to decipher Hieroglyphic Luwian, which occupied him for the remainder of his short life. ${ }^{53}$ Smith was particularly fascinated by the as yet undeciphered inscriptions. A few years earlier he had grappled with the decipherment of the Cypriote syllabary. On 7 November 1871, he delivered before the newly formed Society of Biblical Archaeology (SBA) in London a paper on the reading of the Cypriote inscriptions, which proved to be a solid basis for the subsequent studies of other scholars. ${ }^{54}$

In 1876, Smith discovered and copied the Hieroglyphic Luwian inscription on a huge basalt stele from the tell of Jerablus, identified with the ancient city of Karkemish, attempting to decipher it in situ. The inscription, now known as KARKAMIS A31, had already been seen and sketched by the British consul at Aleppo, Alexander Drummond, more than a hundred years earlier. ${ }^{55}$ Smith made two copies of the KARKAMIS A31 inscription. The first is in his 1875-6 sketchbook, preserved in the British Library. ${ }^{56}$ The other copy of the inscription was prudently sent by Smith on 4 April 1876 from Aleppo to his wife, Mary, in London: "I send to you a copy of a new inscription I have found. I have another copy here but desire you to keep this for me in case I lose the one I have, do not show anyone the copy, as

Exploration Fund Quarterly Statement 5.2 (April 1873), p. 72f. and see also ID., Journal Asiatique, April 1875, p. 373.

51 Dept. of Manuscripts, book identified as Add. MSS. 30423, p. 29; see W.H. Rylands in Proceedings of the Society of Biblical Archaeology, June 5, 1883, p. 147f.; Hawkins, Corpus of hieroglyphic Luwian inscriptions, Vol. I, Part 1, p. 7, n. 47.

52 G. Sмiтн, Assyrian Discoveries, New York, Scribner, Armstrong \& Co, 1875, p. 164 and 422.

53 For the decipherment and interpretation of Hieroglyphic Luwian see Hawkins, Corpus of hieroglyphic Luwian inscriptions, Vol. I, Part 1, p. 13-17 with n. 129, with literature.

54 G. Sмiтн, "On the Reading of the Cypriote Inscriptions", TSBA 1 (January 1872), p. 129-144. On the decipherment of the Cypriot syllabary see M. Pope, The Story of Decipherment. From Egyptian Hieroglyphs to Maya Script, Revised Edition, New York, Thames and Hudson, 1999, p. 123-135, in particular p. 127ff. for the contribution of George Smith.

55 See Hawkins, Corpus of hieroglyphic Luwian inscriptions, Vol. I, Part 1, p. $140 \mathrm{ff}$.

56 Dept. of Manuscripts, book identified as Add. MS. 30425, see Hawkins, Corpus of hieroglyphic Luwian inscriptions, Vol. I, Part 1, p. 141. 
I intend to publish it on my return." 57 The following day, on 5 April, Smith wrote a letter from Aleppo to the Egyptologist Samuel Birch - then Keeper of the Oriental Department of the British Museum - to inform him of the new discovery and to suggest that excavating at Karkemish would be easier and more fruitful than at Nineveh. In this letter, for the first time, Smith used the term "Hittite" to describe the hieroglyphic inscriptions from both Hama and Karkemish: "I have used my time here in making examinations of the country and I have discovered the site of Carchemish, the great Hittite capital. I found many sculptures and an inscription of the Hittite period on a monolith, which I tried in vain to move. I wanted to send it to the Museum; it would form a unique monument there. The characters are in Hittite hieroglyphics (so called Hamath character) and it is the longest inscription yet found". ${ }^{58}$ Smith's assistant, Peter Mathewson (whose biography has recently been discovered in Bulgaria), ${ }^{59}$ reporting the events of March 1876, recorded retrospectively that Smith was among those who thought the Hama Stones were Hittite. ${ }^{60}$

The news of Smith's discovery reached London quickly, but as research currently stands, it is difficult to establish precisely when this occurred. Certainly, it was made known officially at the end of May 1876. On the 29 May 1876, at the $53^{\text {rd }}$ Anniversary Meeting of the Royal Asiatic Society, the renowned Assyriologist Sir Henry Rawlinson gave a preliminary account of the recent discoveries made by Smith. He announced that the inscriptions found at Karkemish were Hittite, and that the Hittites were the chief people occupying the region between Egypt and Assyria. ${ }^{61}$ Rawlinson also declared that he had not yet received any copies of the inscriptions from Smith.

Smith was to die in Aleppo shortly afterwards, on 18 August 1876. It is again from Mathewson's biography that we learn that Smith spent the last weeks of his life trying to decipher the hieroglyphic inscription that he had copied: "I could

57 Quoted after S.V. Panayotov, "George Smith's Identification of Karkemish: From the Account of His Assistant Mathewson", in N. Marchetri (ed.), Karkemish. An Ancient Capital on the Euphrates (OrientLab 2), Bologna, AnteQuem, 2014, p. 48.

58 Letter from George Smith to Samuel Birch, Dep. Orient Antiq. at BM, Aleppo April 5th 1876 (British Museum Original Papers 51 May-July 1876, c5 Aug. 76 Stamp: BM 14 Jun 1876 No. 3024), quoted after Panayotov “George Smith's Identification of Karkemish ..., 2014, p. 49.

59 Panayotov, "George Smith's Identification of Karkemish ..., 2014, and Panayotov Wunsch, "New Light on George Smith's Purchase ...", 2014.

60 Panayotov, “George Smith's Identification of Karkemish ...”, 2014, p. 47.

61 See Th. E. Colebrooke, "Royal Asiatic Society. Proceedings of the Fifty-Third Anniversary Meeting of the Society. Held on the 29th of May, 1876", JRAS NS 9/2 (Apr. 1877), p. I-LXIII (ref. p. XLVIII). 
see how eagerly George Smith got down to studying this inscription in order to find out the key to the script. Very often when I woke up he would look for this key in candlelight trying to discover by guessing, of course, where the words began and finished or if the number of the letters in a word corresponded to those of the name of God or king or high priest. At last I heard him say: 'My efforts here are useless - I will have to wait to go to my books at home!' ... All day his mind wandered, talked of Carchemish and the Hittites and ... he said many times: 'With the clue I have got from the Hittite inscription, I cannot fail to decipher it when I have looked at my papers at home'".62

Interest in Smith's attempt to decipher the hieroglyphic Hittite inscriptions spread within and beyond the borders of Britain. This is palpable from a speech on the subject of "Hittite Inscriptions" given by Rev. Ward in Boston at a meeting of the American Oriental Society (AOS) at the very end of May 1877: "Mr. Smith made a list of about 75 characters, and hoped that he had some clue to their decipherment; and as he discovered the clue to the Cypriote inscriptions, the rumor gave a great deal of hope. But, if so, his note-books do not afford much indication of it." ${ }^{33}$ Ward contacted Sayce to obtain copies of the inscriptions made by Smith, and received the one from Aleppo, but not those from Karkemish, which Sayce said he had seen but did not have in his possession.

Smith's advice to Birch to undertake excavations at Karkemish was followed two years later. In 1878, the British consul in Aleppo, Patrick Henderson, received a firman and conducted the first excavations at Karkemish on behalf of the British Museum (intermittently between 1878 and 1881), during which further inscribed stone blocks were recovered and shipped to London. ${ }^{64}$

\section{Sayce, the Hama Stones and the Hittite hypothesis at the end of the 1870 s}

In 1876, the year in which Wright returned to Ireland and Smith died in Syria, Sayce suggested a correlation between the Hama Stones and the land of KhetaHatti, which apparently indicated the location of this land in Syria. In a lecture delivered to a meeting of the Society of Biblical Archaeology (SBA) on 2 May of that year, Sayce claimed that the Hama writing was Hittite: "Who the inventors were it is of course impossible to determine with certainty, but it is extremely likely

62 Quoted after Panayotov, "George Smith's Identification of Karkemish ..., 2014, p. 47,50 .

63 See W.H. WARD, "On the Hittite Inscriptions, Proceedings at Boston, May 30 ${ }^{\text {th }}$, JAOS 10 (1872-1880), p. cxxxxix-cxli.

64 See D.G. Hogarth, Carchemish. Report on the Excavations at Jerablus on Behalf of the British Museum. Part I: Introductory, London, The Trustees of the British Museum, 1914. 
that they belonged to the great Hittite race" ${ }^{65}$ Sayce showed a list of "Hamathite Hieroglyphics" from Ward's aforementioned 1873 publication, comparing them with the Cypriote characters. Sayce thought, as did Ward and others, that Hieroglyphic Luwian was the origin of the Cypriot syllabary.

Sayce presented his paper to an audience perfectly equipped to understand a philological study of Assyriology, the same platform on which Smith at the end of 1872 had announced his discovery of the Babylonian Flood Story. And the SBA had shown from the outset that it was aware of the importance of the Hama inscriptions, as seen from the reference to them in the Presidential Address on the Progress of Biblical Archaeology held on 21 March 1871. ${ }^{66}$ Despite its name, the work of the SBA did not in fact limit itself to biblical studies. According to its statutes, the aim of the London-based academic Society was to promote "the investigation of the Archaeology, Chronology, Geography, and History, of Ancient and Modern Assyria, Arabia, Egypt, Palestine, and other Biblical Lands, the promotion of the study of the Antiquities of those countries, and the preservation of a continuous record of discoveries, now or hereafter to be in progress"; 67 "Its scope is Archaeology, not Theology; but to Theology it will prove an important aid". ${ }^{68}$ Furthermore, among the aims not programmatically declared by the SBA was that of turning Assyriology into an academic discipline. In the spring of 1876, just when Sayce gave his lecture on the "Hamathite Inscriptions", "classes" in Assyrian were being held at the SBA. These were considered to be an "experiment", the hope being that they would lead to the establishment of Assyriology as an academic discipline: indeed, at this time there was no university teaching of Assyriology in England, as Sayce was not appointed at Oxford until 1891. ${ }^{69}$

65 A.H. SAyce, "The Hamathite Inscriptions", TSBA 5 (1877), p. 27; see also SAyce, Reminiscences, London, Macmillan, 1923, p. 161f.

66 S. Birch, "The Progress of Biblical Archaeology: An Address", TSBA 1 (January 1872), p. 1-12 ("Inscriptions of a novel character have also been found in the neighbourhood of Hamath. Of these it would be premature to give any opinion, but as inquirers and travellers will obtain copies of further specimens, it will be hereafter seen if they throw any important light upon the history of that portion of the East., p. 10f.).

67 See Transactions of the Society of Biblical Archaeology (TSBA) 1 (January 1872), p. ii (Introduction). On the SBA and its aims see, among others, P.R.S. Moorey, A Century of Biblical Archaeology, Cambridge, Lutterworth, 1991, p. 1-24, and E. Roвson, "Bel and the Dragons: Deciphering Cuneiform after Decipherment", in M. Brusius, K. Dean, C. Ramalingam (eds), William Henry Fox Talbot: Beyond Photography (Studies in British Art 23), New Haven, Yale University Press, 2013, p. 202, $213 f$.

68 Birch, "The Progress of Biblical Archaeology: An Address", 1872, p. 12.

69 A.H. SAYce, Lectures upon the Assyrian Language and Syllabary: Delivered to Students of the Archaic Classes, London, Samuel Bagster and Sons, 1877 with the Review in The North American Review 127 (265), 1878, p. 522f. See also E.A. W. Budge, 
Sayce's lecture appeared in the fifth volume of the Transactions of the SBA (June 1876), before the advent of the speedier Proceedings, published on a monthly basis, which were to be launched the following year. Sayce argued on several occasions that he had not heard of Wright's 1874 article when he delivered his paper on the "Hamathite Inscriptions" at the SBA in May 1876. He affirmed that Wright's article was never widely read because it was published in the pages of a periodical better known to theologians than to orientalists. And this became the accepted version. ${ }^{70}$ In general, one cannot help noting that, at least within the circles of the SBA, Wright's memorandum was always emphasised at the expense of his article in the British and Foreign Evangelical Review, as can be seen, for instance, in W. Harry Rylands' article of 1884 in the Transactions of the SBA, of which he was Secretary. ${ }^{71}$

The question whether Sayce was unaware of Wright's 1874 article is debated. ${ }^{72}$ Wright took him at his word, believing that Sayce had reached his conclusions by following his own intellectual path, and always held Sayce in high esteem: "He has the archaeological imagination combined with genius, and his steps are so scholarly, that even when he errs he advances towards the final solution".73 However, it seems to me that one should rather ask whether Sayce, when he gave his lecture on 2 May 1876, already knew what Smith had discovered in Karkemish and what he thought about the hieroglyphic inscriptions from Hama. In the 1870s, Sayce was not in fact connected with Wright, as their collaboration dates to the

By Nile and Tigris. A Narrative of Journeys in Egypt and Mesopotamia on Behalf of the British Museum between the Years 1886 and 1913, London, 1920, I, p. 11-13 and ID., The Rise and Progress of Assyriology, p. 186. For the reform of Oxford University see M.G. Brock, M.C. Curthoys (eds), The History of the University of Oxford, Vol. VII, Nineteenth-Century Oxford, Part 2, Oxford, Oxford University Press, 2000, especially the chapter by O. Murray, "Ancient History 1872-1914", p. 333-360.

70 A.H. SAYce, "The Monuments of the Hittites", TSBA VII/2, January 1881 (1882), p. 248; ID., The Hittites: The Story of a Forgotten Empire (By-Paths of Bible Knowledge XII), London, Religious Tract Society, 1888, p. $59 f$.

71 W.H. Rylands, "The Inscribed Stones from Jerabis, Hamath, Aleppo, \&c., TSBA VII/2, 1881 (1882), p. 429-442.

72 See J. DE Roos, "Early Travellers to Boğazköy", in Th.P.J. van den Hout, J. DE Roos (eds), Studio historiae ardens. Ancient Near Eastern Studies Presented to Philo H.J. Houwink ten Cate on the Occasion of his 65th Birthday (PIHANS 74), Leiden, 1995, p. 267f. and M. WeEden, "Before Hittitology. The First Identifications of the Hittites in England", paper read November 14, 2015, at the Colloquium organized by Z. Kızıltan, A. Schachner, M. Doğan-Alparslan, M. Alparslan: The Discovery of an Anatolian Empire. A Colloquium to Commemorate the 100th Anniversary of the Decipherment of the Hittite Language, Istanbul Archaeological Museum-Library. 
period following Wright's return to Ireland and particularly to the $1880 \mathrm{~s},{ }^{74}$ whereas he was linked quite closely to the British Museum and to Smith. It is within this circle that we must locate Sayce's path that independently led him to reach the same conclusion as Wright. Above all, Wright was eager for external corroboration of the veracity of the Old Testament. Sayce's contribution was rather an attempt to decipher the Hama inscriptions based on the decipherment of Cypriote, on which Smith had worked some years earlier.

Sayce had boundless admiration for Smith's qualities as a decipherer, as is clear from the obituary he wrote in the weekly illustrated scientific journal Nature: Smith was "a genius with the heaven-born gift of divining the meaning of a forgotten language and discovering the clue to an unknown alphabet" ${ }^{75}$ A similar appreciation for Smith's brilliance in decipherment can be found in the Preface to History of Sennacherib, a book by Smith that Sayce edited in 1878: "Mr. Smith's wonderful instinct of decipherment carried him safely through sentences which were a puzzle to other scholars".76 Years later, while in Aleppo, Sayce visited the grave of George Smith to pay tribute to his memory. ${ }^{77}$

Unpublished documents currently being studied will be able to shed further light not only on the relationship between Sayce and Smith, but also on the exact timing of the arrival in London of the news sent by Smith in the spring of 1876 concerning the Karkemish inscription.

However, the step that followed should undoubtedly be attributed to Sayce alone: in a lecture given at the Athenaeum Club on 4 August 1879, then published in the weekly periodical The Academy, Sayce proposed that all the monuments with associated hieroglyphic inscriptions from Syria and Anatolia (among which we may cite Yazılıkaya and Nişantaş, Karabel, İvriz and Sipylus) should be attributed to the Hittites. ${ }^{78}$ Sayce himself described this as "my Hittite theory of 1879 " 79

74 Wright's book of 1884, titled The Empire of the Hittites, included, among other things, a philological contribution by Sayce, who a few years later, in 1888, was to bring out a monograph of his own on the subject, The Hittites: The Story of a Forgotten Empire. SAYce, "George Smith", 1876, p. 421.

76 History of Sennacherib, 1878, p. iv. Further examples of Sayce's esteem and appreciation for Smith can be found in the Preface to The History of Babylonia, another of Smith's books edited by Sayce, published in London by the Society for Promoting Christian Knowledge in 1877, in the new edition by Sayce of Smith's The Chaldean Account of Genesis in 1880, and in Sayce's Reminiscences in 1923.

77 Sayce, Reminiscences, p. 368. For a description of Smith's grave see F.D.R. SÁnchez, "La tumba de George Smith en Alepo", AuOr 24 (2006), p. $275 f$.

78 A.H. SAYce, "The Origin of Early Art in Asia Minor", The Academy, Aug. 16, 1879, p. 124.

79 See S. Alaura, "Lost, Denied, (Re)Constructed: The Identity of the Hittites and Luwians in the Historiographical Debate of the Late $19^{\text {th }}$ and Early $20^{\text {th }}$ Centuries", 
The Athenaeum Club, at 107 Pall Mall, south of Burlington House, was particularly popular among the scientific and literary elite ${ }^{80}$ and was one of the places of meeting and discussion for the orientalists of the 1870s in which the initial debate about the Hittites developed. The orientalists were members of a dining club that included, among others, the already mentioned Rawlinson and Layard, James Fergusson (the architect and art historian specialising in ancient Mesopotamian, Egyptian and Indian art, and manager of the Crystal Palace Company) and William Sandys Wright Vaux (who from November 1875 until his death was Secretary of the Royal Asiatic Society, and whose publications did much to popularise the oriental antiquities discovered by Layard and other travellers). Their dinners, which took place at seven o'clock on Sunday evening at the Athenaeum Club, are described in abundant detail by Sayce in his autobiography. ${ }^{81} \mathrm{It}$ is in this context that Sayce probably discussed in a preliminary way the idea that the inscriptions from both Syria and Anatolia should be attributed to the Hittites. Therefore, during the 1870s the debate about the Hittites was conducted in a widespread and dynamic way. Every space in London where the learned met and mingled could serve as a stage upon which orientalists showed each other the progress they had made in their researches, testing out their new ideas. Public spaces could double as places of learning. Yet a range of humbler, everyday interactions also played a crucial role in the progress of oriental studies.

On the other hand, 1879 marked a further turning point for Sayce: he gained first-hand knowledge of the Hittite territory, Anatolia. A few days after his Athenaeum Club lecture, Sayce began the first of his travels through the East. During his journey to Smyrna, he visited the rock reliefs at Karabel and Akpınar. ${ }^{82}$ Layard was now the British ambassador at Constantinople, and their friendship undoubtedly played a significant role in Sayce's work at the end of the 1870s. The

in G. Garbati, T. Pedrazzi (eds), Transformations and Crisis in the Mediterranean. "Identity" and Interculturality in the Levant and Phoenician West during the $12^{\text {th }} 8^{\text {th }}$ Centuries BCE. Proceedings of the International Conference held in Rome, CNR, May 8-9 2013 (Supp. RSF XLII 2014), Pisa-Roma, Fabrizio Serra editore, 2015, p. 30; also Sayce, Reminiscences, p. 162.

80 For a history of the Athenaeum Club see H. WARD, History of the Athenaeum 18241925, London, William Clowes and Sons, 1926; F.R. Cowell, The Athenaeum, Club and Social Life in London, 1824-1974, London, Heinemann, 1975; B. BLACK, A Room of His Own: A Literary-Cultural Study of Victorian Clubland, Athens, Ohio University Press, 2012, especially p. 59-64.

81 SAYce, Reminiscences, p. $123 f$.

82 A.H. SAyce, "The Hittites in Asia Minor", The Academy, Nov. 1, 1879, p. 321 and idem, Reminiscences, p. 168f., $200 \mathrm{f}$. 
relationship between Sayce and Layard, scarcely mentioned in Layard's memoirs or in Lady Layard's diaries for the same period, ${ }^{83}$ has not so far been adequately investigated. Layard introduced Sayce to the sultan, in order to facilitate his access to the Anatolian monuments, and fostered his friendship with Heinrich Schliemann, the excavator of Hissarlık (Troy). Schliemann, who in the mid-1870s was lauded and derided in equal measure, fascinated Sayce as much as Smith had, ${ }^{84}$ to the extent that in 1882 Sayce tried to encourage Schliemann, who had just completed a decade of excavation at Troy, to dig at Boğazköy. ${ }^{85}$

Sayce expressed his gratitude to Layard in an unpublished letter he wrote on his return to England, dated 19 November 1879: "Dear Sir, I ought to have written long ago to thank you for your kind offices wh[ich] smoothed the way for me at Smyrna, and I must apologise much for not having done so. My wanderings in Lydia were more successful than I could have hoped. I had the pleasure of seeing and copying the second pseudo-Sesostris described by Herodotus, as well as of having the remains of the old Greek road wh[ich] ran close to it. My squeezes and copies of the first pseudo-Sesostris, already known from [*Texier's] drawing, show that the inscription accompanying it is Hitthite, the characters being identical with those on the monuments recently sent to the British Museum from Carchemish; and they prove, therefore, that Hitthite arms and influence must once have penetrated as far as the Aegean Sea. So 'the missing link' between the art of Assyria and Lydia is found".86

83 See S. Kuneralp (ed.), The Queen's Ambassador to the Sultan. Memoirs of Sir Henry A. Layard's Constantinople Embassy, 1877-1880, Istanbul, The Isis Press, 2009 and ID., Twixt Pera and Therapia. The Constantinople Diaries of Lady Layard, Istanbul, The Isis Press, 2010.

84 For the relationship between Sayce and Schliemann see S. Duesterberg, Popular Receptions of Archaeology. Fictional and Factual Texts in $19^{\text {th }}$ and Early $20^{\text {th }}$ Century Britain (Historische Lebenswelten in populären Wissenskulturen - History in Popular Cultures 14), Bielefeld, Transcript Verlag, 2015, p. 295-298. For the criticisms of Schliemann in the mid-1870s see for example the article "Dr. Schliemann" in the New York Times, November 10, 1876.

85 Sayce, Reminiscences, p. 220 and see also S. Alaura, "Nach Boghasköy!" Zur Vorgeschichte der Ausgrabungen in Boğazköy-Hattuša und zu den archäologischen Forschungen bis zum Ersten Weltkrieg. Darstellung und Dokumente (13.SendschriftDOG), Berlin, 2006, p. 25f.

86 British Library, Layard Papers, Vol. XCIX, Add MS 39029, f. 250. I wish to thank Cecilia Riva for kindly making available to me the transcription of Sayce's letter to Layard, and also Stefania Ermidoro for a number of bibliographical suggestions relating to Layard. 
From this point on, discoveries and publications about the Hittites proceeded at a more rapid pace. From 1879 onwards, Sayce's works were frequently requested by societies and journals interested in the relationship between archaeology and the Bible. Many of his articles were published in inexpensive penny dailies, accessible to a broad audience. Sayce's great ability to communicate was highly prized, and his clarity of exposition was unparalleled, as recorded by E.A. Wallis Budge, later keeper of Egyptian and Assyrian Antiquities at the British Museum: "No one who ever heard Sayce lecture to the students of the Archaic Classes can forget his lucid exposition, and the clear and forceful language in which he clothed his learning". ${ }^{87}$

Sayce's provocative "Hittite Theory" was not favourably received in all quarters, and a split opened up in the scientific community. This marks the beginning of the real debate concerning the Hittites that would characterise the 1880s.

\section{Silvia Alaura}

Istituto di Studi sul Mediterraneo

Antico (ISMA), CNR, Rome

Via Salaria km 29,300

I-00015 Monterotondo Scalo (RM)

silvia.alaura@isma.cnr.it

87 Wallis Budge, The Rise and Progress of Assyriology, p. $185 f$. 